\title{
Carte-de-visite Photograph of Maximilian von Habsburg's Execution Shirt
}

\author{
Eleanor A. Laughlin
}

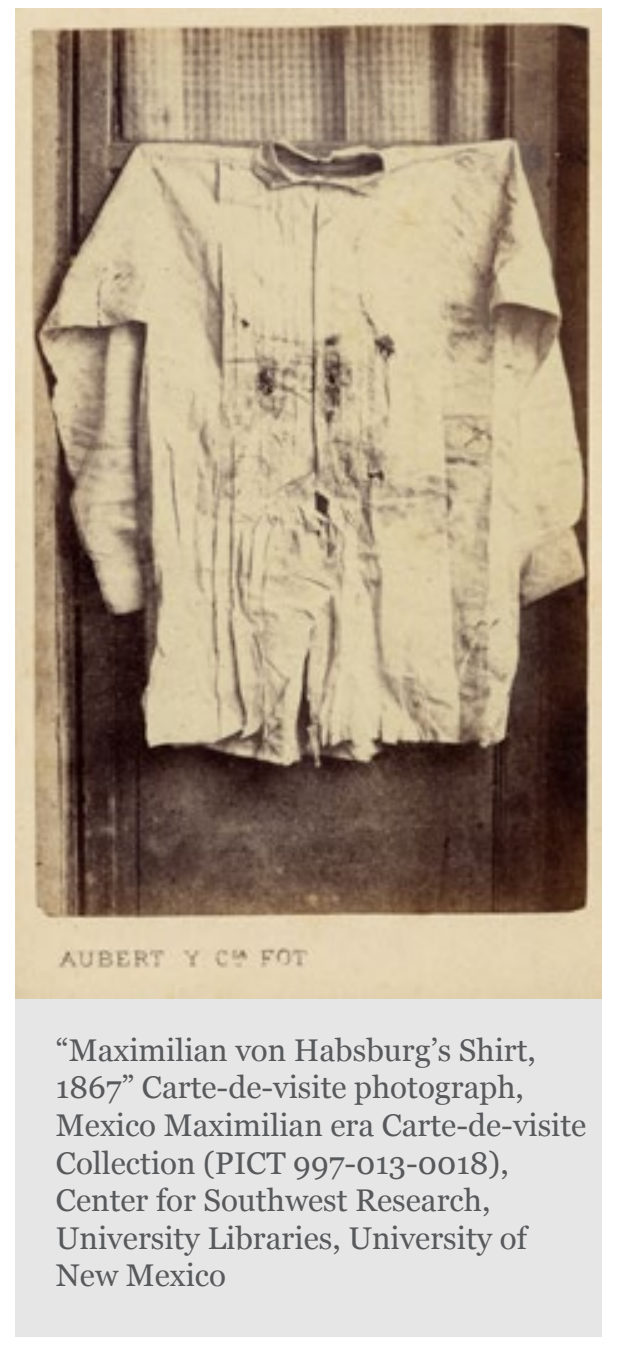

A carte-de-visite ${ }^{1}$ of Maximilian von Habsburg's shirt (Fig. 1) was one of a series on the topic of the former emperor's execution that circulated in the Americas and Europe after his death in Mexico in $1867 . .^{2}$ The series included pictures of Maximilian's corpse, his personal effects bloodied from execution, and the locations associated with his death. ${ }^{3}$ The carte-de-visite of the shirt Maximilian wore at the time of the execution sold widely on the commercial market and is of particular interest due not only to its subject matter, but also its potential use. Citizens of many countries on both sides of the Atlantic purchased objects like this one, whether they opposed or supported the emperor's regime. As an icon of the execution, the carte-de-visite of Maximilian's shirt served a variety of functions. First, it satisfied a sensational interest in the political event. Second, it served as a mourning object, offering the living both visual and tactile connections to the deceased to aid in the grieving process. Finally, the carte-de-visite of Maximilian's shirt may have functioned in the Mexican religious context as a relic or 
object of reverence.

The photograph of Maximilian's shirt has the air of a mourning object. In the nineteenth-century, cartes-de-visite often featured post-mortem portraits and were associated with mourning practices. The bereaved used carte-de-visite backings and albums to preserve and admire non-photographic tokens of remembrance such as clothing, jewelry, hair, and items that had come into contact with the physical body of the deceased. ${ }^{4}$ Mourners might use the photographs themselves as a focus for the gaze. The carte-de-visite of Maximilian's shirt invites this kind of viewing. The shirt is central to the composition; it is a solitary object that represents the emperor's life and death, and provides the details of his execution by firing squad. The photographer did not simply document the event; his portrait of the shirt confronted the viewer with evidence of the emperor's death in the form of the executioner's bullets and gunpowder, and the blood that poured from Maximilian's body in his last moments of life. The image's widespread circulation made it available to a large audience with a range of political and social affiliations. In contemplating the photograph of the shirt, a republican viewer might celebrate Maximilian's demise, while a monarchist could feel sympathy for Maximilian and join in the grieving process. The availability, affordability, and subject matter of the carte-de-visite of Maximilian's shirt facilitated either function.

In addition to interest in photographs of Maximilian's effects, contemporary Mexicans of diverse political allegiances were fascinated with souvenirs from his execution. Memoirs written about the Second Mexican Empire (1864-67) attest to the pursuit of relics from Maximilian's remains; crowds in Querétaro tore at the hair and clothing of the deceased emperor and dipped their handkerchiefs in his blood. ${ }^{5}$ The carte-de-visite may have been interpreted as a relic itself. The portrait-like representation of the shirt suggests a transfer of power from the actual shirt to its image. ${ }^{6}$ In Mexico, it is hard to think of transferred images and textiles imbued with power without recalling the Virgin of Guadalupe, the country's patron saint. ${ }^{7}$ The holiest relic of the Virgin is the tilma or cloak of the indigenous peasant Juan Diego, onto which the Virgin transferred her image, saturating the cloth with the visible presence of the divine. Nineteenth-century viewers similarly believed that photographic images held some aspect of the sitter's spirit, captured through exposure, just as the Virgin of Guadalupe's image and part of her essence were captured in Juan Diego's tilma. ${ }^{8}$

Photographic portraiture held an important place in the private context of Mexican households. The photograph lent a surreal quality to family altars, small in-home devotional centers that grew in popularity in the nineteenth century, where families might display ancestral, holy, or meaningful objects. Alongside images of the Virgin, postmortem portraits taken of family members were placed on shelves or tables with candles, rosaries, flowers, and relics. For living family members, the latter items were deemed to be endowed with the divine just as the photos were felt to contain some presence of the deceased person whose body had passed on. ${ }^{9}$

In a Mexican religious context, the transferred image of Maximilian's shirt invited uses similar to those of original relics. The nineteenth-century Mexican practice of placing 
pictures and other objects on home altars, and the iconic nature of the carte-de-visite of Maximilian's shirt, suggest a new context for political photographs in Mexico. It would not have been surprising to encounter cartes-de-visite associated with the emperor on home shrines of the period, as they would have brought the essence of the original into the home of the mourner. In general, carte-de-visite photographs of Maximilian underscore the importance of photographs in mid-to-late nineteenth century Mexico. Photography not only served propaganda purposes, but also played a role in the everyday rituals of life-allowing average citizens to hold a piece of history and connect to the events and people of their time.

(C) Eleanor A. Laughlin

\section{Citation Guide}

1. Eleanor A. Laughlin, "Carte-de-visite Photograph of Maximilian von Habsburg's Execution Shirt," Object Narrative, in Conversations: An Online Journal of the Center for the Study of Material and Visual Cultures of Religion (2016), doi:10.22332/con. obj.2016.1

Laughlin, Eleanor A. "Carte-de-visite Photograph of Maximilian von Habsburg's Execution Shirt." Object Narrative. In Conversations: An Online Journal of the Center for the Study of Material and Visual Cultures of Religion (2016). doi:10.22332/con. obj.2016.1

\section{Notes}

1. Cartes-de-visite were originally small calling cards; in 1854 French photographer André Adolphe Eugène Disdéri patented them to include portrait photographs. The photograph was usually an albumen print pasted to a thicker piece of cardstock measuring approximately two and a half by four inches. By the 1860s, the small-format photographs became such a trend that carte-de-visite photography studios opened across Europe, Britain, and the Americas to accommodate demand. Middle- and upperclass members of society collected carte-de-visite portraits of friends and family and stored them in early examples of photo albums.

2. Maximilian von Habsburg (1832-1867) was an Austrian Archduke, the younger brother of Austrian Emperor Franz Josef I (1830-1916). Through the combined efforts of a group of Mexican monarchists and the French Emperor Napoleon III, Maximilian was offered and accepted the Imperial Throne of Mexico in 1864. He served as emperor until he was captured by Benito Juarez's republican troops and executed by firing squad in 1867.

3. For more information on cartes-de-visite related to Maximilian's execution, see Pamela M. Jones, Edouard Manet and the Execution of Maximilian (Providence: 
Brown University Press, 1981), Patricia Priego Ramirez and José Antonio Rodríguez, La manera en que fuimos, Fotografía y sociedad in Querétaro: 1840-1930 (Mexico City: Jose Manuel Rivero Torres, 1989), Juliet Wilson-Bareau ed., Manet: The Execution of Maximilian (London: National Gallery Publications, 1992), John Elderfield, Manet and the Execution of Maximilian (New York: Museum of Modern Art, 2006), and Eleanor Laughlin, "Posed and Deposed: Carte-de-visite Photographs of Maximilian von Habsburg during Mexico's Second Empire (1864-67)" (Ph.D. dissertation, University of Florida, 2014). For more information about visual culture in general during Mexico's Second Empire, see Esther Acevedo, "La creación de un proyecto imperial," in Testimonios artísticos de un episodio fugaz, ed. Esther Acevedo (Mexico City: Museo Nacional de Arte, 1995). 